\title{
COVID-19 and Movement Control Order (MCO) in Malaysia: Access to Financial and Social Capital for Microenterprise Sustainability
}

Naimah Zaini, Nor Asyiqin Salleh, Maizura Meor Zawawi, Hafidzah Hashim

To Link this Article: http://dx.doi.org/10.6007/IJARBSS/v11-i12/11238 DOI:10.6007/IJARBSS/v11-i12/11238

Received: 07 October 2021, Revised: 11 November 2021, Accepted: 30 November 2021

Published Online: 21 December 2021

In-Text Citation: (Zaini et al., 2021)

To Cite this Article: Zaini, N., Salleh, N. A., Zawawi, M. M., \& Hashim, H. (2021). COVID-19 and Movement Control Order (MCO) in Malaysia: Access to Financial and Social Capital for Microenterprise Sustainability. International Journal of Academic Research in Business and Social Sciences, 11(12), 1337-1348.

\section{Copyright: @ 2021 The Author(s)}

Published by Human Resource Management Academic Research Society (www.hrmars.com) This article is published under the Creative Commons Attribution (CC BY 4.0) license. Anyone may reproduce, distribute, translate and create derivative works of this article (for both commercial and non0-commercial purposes), subject to full attribution to the original publication and authors. The full terms of this license may be seen

at: http://creativecommons.org/licences/by/4.0/legalcode

Vol. 11, No. 12, 2021, Pg. $1337-1348$

Full Terms \& Conditions of access and use can be found at http://hrmars.com/index.php/pages/detail/publication-ethics 


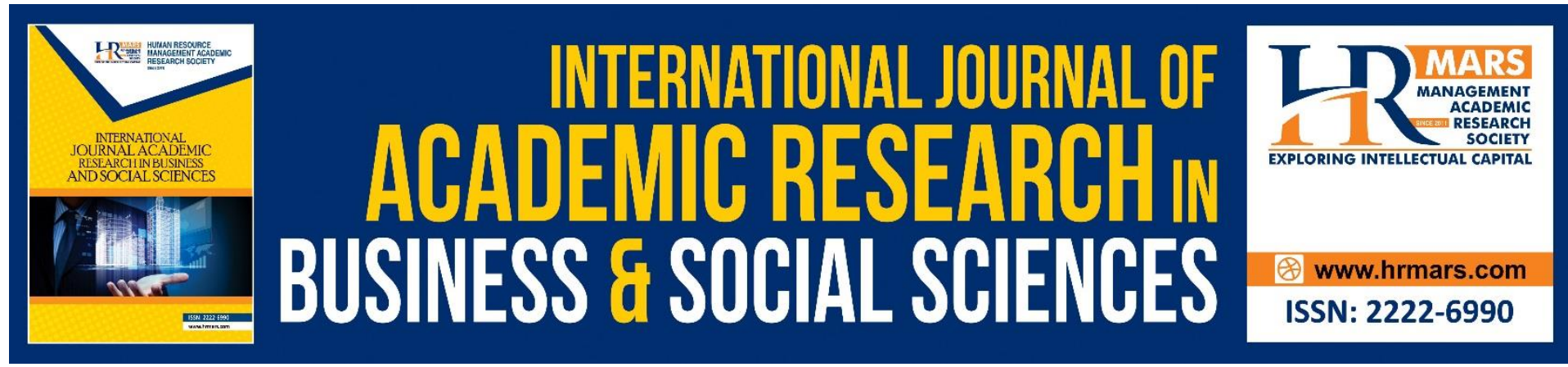

\title{
COVID-19 and Movement Control Order (MCO) in Malaysia: Access to Financial and Social Capital for Microenterprise Sustainability
}

\author{
Naimah Zaini, Nor Asyiqin Salleh, Maizura Meor Zawawi, \\ Hafidzah Hashim \\ Faculty of Accountancy, Universiti Teknologi MARA, Perak Branch, Tapah Campus, 35400, \\ Tapah Road, Perak, Malaysia \\ Email: naima058@uitm.edu.my
}

\begin{abstract}
Micro, small and medium enterprises (MSMEs) have always been recognized as a major contributors to the Malaysian economy. The global COVID-19 outbreak has severely affected the economic landscape of Malaysia and impacted the microentrepreneurs because they mainly do not have enough financial resources to support their business. However, as the COVID-19 cases keep increasing, the third MCO (MCO 3.0) has been imposed and this situation continues to disrupt the business activities of microentrepreneurs. Despite the stimulus packages provided by the government to cushion the impact on businesses, different microentrepreneurs have different experiences and capabilities to mitigate the negative impact of COVID-19. The purpose of this study is to understand the challenges faced by microentrepreneurs during MCO 3.0 and to investigate to what extent their access to resources influences their business strategy. This study employed a qualitative approach and collected data using phone interviews with five selected microentrepreneurs in Perak: The findings of this study depicted the main challenges surrounding these microentrepreneurs are a lack of financial resources and supply chain issues. This study also found the access to financial capital and social capital influence microentrepreneurs to undertake business strategies that can ensure their businesses sustain during the pandemic crisis.
\end{abstract}

Keywords: COVID-19, MCO, Microentrepreneurs, Sustainability, Malaysia

\section{Introduction}

COVID-19 outbreak has been causing hostile effects globally. It marks the utmost challenges faced by everyone around the world. The virus was identified in Wuhan, China in December 2019, and in March 2020, World Health Organization (WHO) declares this outbreak as a pandemic following the increased cases of infected patients and fatalities in many countries. Malaysia is no exception to the COVID-19 outbreak where the increase of infection clusters has induced the government to take drastic action by implementing the Movement Control Order (MCO). Since 18 March 2020, the Government of Malaysia had imposed the first MCO (MCO1.0), which was implemented as a preventive measure to curb the spread of the virus. The primary purpose of implementing this measure is to prevent the spread of the COVID-19 
infection chain by restricting the social activities whereby unnecessary individual movements are not allowable, and the international borders and cross-state travelings are also restricted (Radzi et al., 2020).

The implementation of MCO has in turn, affected socioeconomic activities among the communities and businesses in Malaysia. The MCO has pushed many peoples below the poverty line due to the lost of jobs and sources of income. Many individuals either have no fixed income and employment or have been terminated when their companies are forced to shut down business operations. Businesses especially micro, small, and medium enterprises (MSMEs) were not prepared for this situation. Based on the survey by the Department of Statistics Malaysia, $67.8 \%$ of MSMEs do not have any sales or revenues during the period of MCO and $53.4 \%$ of MSMEs will only be able to survive one or two months with full-time payment given to the employees. The challenges faced by MSMEs have urged the government to take imperative action to aid the businesses to survive the challenges brought by the COVID-19 pandemic. Even in the pre-COVID business environment, MSMEs were found prone to suffer capital constraints as compared to large enterprises and corporate entities (Lacina \& Vavřina, 2013). Thus, the Malaysian government has announced business supports and assistance in the form of the stimulus package to cushion the economic fallout and these packages can be categorized into two; Economic Stimulus Package Prihatin Rakyat (PRIHATIN) and PRIHATIN PLUS (Mustapa \& Mohamad, 2021).

On 7 June 2020, Prime Minister Tan Sri Muhyiddin Yassin announced that the Conditional Movement Control Order (CMCO) would end on 9 June 2020 and be replaced with the Recovery Movement Control Order (RMCO). The government eased restrictions under the condition that the public take responsibility in adhering to the SOPs that have been set. However, due to the sudden increase in infection cases, the government has decided to reinforce the second MCO (MCO 2.0). The MCO 2.0 was implemented on 13 January 2021 in 6 states; Penang, Selangor, Wilayah Persekutuan, Melaka, Johor and Sabah. Since then, the number of reported cases continues to provide a worrying sign. Due to the exponential spike in the infection rates since the beginning of May 2021, the Malaysian government announced the third MCO (MCO 3.0) which came into effect on 1 June until 14 June 2021. The MCO 3.0 is a total scale lockdown where only selected industries are permitted to operate. At the time of writing this paper (fourth week of June), the MCO 3.0 is still being implemented and Malaysia is still fighting with the highest number of COVID-19 cases and fatality rates. While businesses are still recovering from the impacts of MCO 1.0 and $\mathrm{MCO} 2.0$, this prolonged $\mathrm{MCO}$ has impacted microentrepreneurs to sustain their businesses in the uncertain period. The SME Association predicted that $37.7 \%$ of businesses were bound to closure and $40 \%$ of businesses will face financial difficulties with 2 million people unemployed by the end of the lockdown.

Nevertheless, the Malaysian government continues to provide additional financial support to the MSMEs during MCO 3.0. In addition to the stimulus package provided during MCO 1.0 and MCO 2.0, the Malaysian Government has announced the National Recovery Plan in June 2021 to increase public healthcare facilities, support public welfare, and support business continuity. With regards to MSMEs, the government will be providing additional assistance under the Prihatin Special Grant (GKP) 4.0 program, and give MSMEs one-off payments of RM500 in September and another RM500 in November 2021. As such, this plan is expected 
to help MSMEs in their business' post-MCO recovery. The state government in Malaysia has also planned its Stimulus Package to further support the recovery of MSMEs in each state. Under Perak Stimulus Package 2021 which has been launched on $2^{\text {nd }}$ June 2021, the Perak State government has allocated RM19.5 million to assist affected peoples and businesses in Perak.

The instability in economics threatens the sustainability of small enterprises. Small businesses such as microenterprises face financial and non-financial constraints which cause unfavorable business performance (Mittal \& Raman, 2021). However, financial constraints such as insufficient capital are the most concerning (Bose, 2013) while access to financial capital is a key determinant for businesses to operate, expand and grow (Singh \& Kaur, 2019). Other than tangible resources like financial capital, intangible resources such as social capital could help the entrepreneurs cope with the challenging role and enhancing their business's chances of success (Baluku et al., 2018). In Malaysia, access to efficient development initiatives to improve the social competencies of entrepreneurs is also considered as one of the building blocks for sustainable microenterprises (Mustapa et al., 2018).

Previous studies revealed microenterprises in Malaysia are facing a tremendous impact during MCO because they mainly do not have enough financial resources and capital to support their business, lack financial management skills, supply chain issues, and outdated marketing strategies (Hamdan et al., 2021; Tajudin et al., 2021; Fabeil et al., 2020; Che Omar et al., 2020). Despite the financial aids provided in the stimulus package by the government since MCO 1.0, previous studies focus solely on the impact of the crisis and approach and coping strategies by microentrepreneurs to mitigate the impact of COVID-19. There is a paucity of studies that investigate further the aspects of access of resources particularly financial and social capital into business strategy for business sustainability during MCO. During a critical and unexpected crisis, the microentrepreneurs must have efficient resource management, strategies used, and effectiveness in addressing challenges. This leads to the following objectives of this study:

1. To explore the challenges faced by microentrepreneurs during MCO 3.0

2. To investigate to what extent their access to financial and social capital influences the microentrepreneurs' business strategy for survival and sustainability of their businesses.

The remainder of this paper is structured as follows. The second section provides a review of the available literature. The third section discusses the methodology employed in this study. The fourth section presents the results and findings. The fifth section presents the summary and conclusion.

\section{Literature Review}

\section{Microenterprise in Malaysia}

Microenterprise comprises $78.7 \%$ of all businesses in Malaysia (Sabli et al., 2018). Khaw (2019) stated that 694,000 microenterprises in Malaysia make up $75 \%$ of total firms. His study found that $94 \%$ of microenterprises are mainly in the service sector. A review of the definition of MSMEs was undertaken in 2013 and endorsed at the $14^{\text {th }}$ National SME Development Council (NSDC) meeting in July 2013. The definition covers all sectors namely services, manufacturing, agriculture, construction, mining, and quarrying. There are three categories 
of Malaysian SMEs; microenterprises, small and medium. NSDC defines microenterprises as businesses with annual sales turnover of less than RM300,000 with less than five full-time employees with primarily involved in the manufacturing, agro-based industries, service, and other sectors. As they are small, microenterprises are much more flexible and responsive to market as well as demand from customers. This type of business started with a small amount of capital advanced from a bank or other organization. Table 1 provides characteristics of MSMEs by NSDC across all economic sectors:

Table 1: Definition by the size of operation of MSMEs in Malaysia

\begin{tabular}{|c|c|c|c|}
\hline Category & Micro-enterprises & Small-enterprises & $\begin{array}{l}\text { Medium- } \\
\text { enterprises }\end{array}$ \\
\hline Manufacturing & $\begin{array}{l}\text { Sales turnover of less } \\
\text { than RM300,000 or } \\
\text { full-time employees } \\
\text { less than } 5 \text {. }\end{array}$ & $\begin{array}{l}\text { Sales turnover from } \\
\text { RM300,000 to less } \\
\text { than RM15 million or } \\
\text { full-time employees } \\
\text { from } 5 \text { to less than } \\
75\end{array}$ & $\begin{array}{l}\text { Sales turnover from } \\
\text { RM15 million to not } \\
\text { exceeding RM50 } \\
\text { million or full-time } \\
\text { employees from } 75 \\
\text { to not exceeding } 200\end{array}$ \\
\hline $\begin{array}{l}\text { Services and other } \\
\text { sectors }\end{array}$ & $\begin{array}{l}\text { Sales turnover of less } \\
\text { than RM300,000 or } \\
\text { full-time employees }\end{array}$ & $\begin{array}{l}\text { Sales turnover from } \\
\text { RM300,000 to less } \\
\text { than RM3 million or } \\
\text { full-time employees } \\
\text { from } 5 \text { to less than } \\
30\end{array}$ & $\begin{array}{l}\text { Sales turnover from } \\
\text { RM3 million to not } \\
\text { exceeding RM20 } \\
\text { million or full-time } \\
\text { employees from } 30 \\
\text { to not exceeding } 75\end{array}$ \\
\hline
\end{tabular}

Source: Guideline for SME Definition by SME Corp. Malaysia

A small or micro-enterprise is generally a one-man show, where all the activities are mainly carried out by one of the partners or directors and the others are simply as sleeping partners who mainly provide funds. Larson \& Shaw (2001) characterized microenterprises as follows:

- Mostly family owned with family members working in the business

- Driven by one person

- Located primarily in rural areas

- Involved in trading and manufacturing

- Characterized by multiple start-ups and failure rates

- Founded primarily by women

- Operated on a small basis with low-income earnings

MSMEs in Malaysia generally rely on entrepreneurship development and financing supports for them to grow. The government provides comprehensive entrepreneurship and SME development program comprising of access to financing, human capital development, market access, innovation, and technology adoption and infrastructure (www.smeinfo.com.my). Currently, these entrepreneurship and development programs are supported by selected Ministries and government agencies. Effective business programs by the government are essential for small businesses like micro-enterprises to ensure their sustainability to meet business challenges in the competitive global business environment (Mustapa \& Mohamad, 2021). Through these programs, microenterprises will have access to working capital in the form of small loans extended to low-income micro-entrepreneurs and improving 
microentrepreneurs' competencies in business management and increase in revenue for better performance (Wan Mustapa et al., 2018). Besides, access to these critical resources is crucial for business success and increases the well-being of micro-entrepreneurs (Marshall et al., 2020).

\section{Financial and Social Capital}

Microenterprises are facing a tremendous impact during MCO because they mainly do not have enough financial resources and capital to support their business (Tajudin et a; Hamdan, Kassim, \& Lai, 2021), reduce in cash flows due to losses in daily income (Fabeil, Pazim, \& Langgat, 2020), operation disruption (Che Omar et al., 2020) and laying off workers and supply chain disturbance (Fabeil et al., 2020; Hamdan et al., 2021; Tajudin et al., 2021). Furthermore, microenterprises are found to have difficulty accessing stimulus package and causes them to the potential risk of bankruptcy (Che Omar, Ishak, \& Jusoh, 2020). The business possesses certain unique resources and capabilities to achieve a competitive advantage. The theory of Resource-Based View developed by Barney (1991) posits those resources and capabilities are valuable, rare, inimitable, and non-substitutable and they can constitute a source of competitive advantage.

From a resources perspective, access to scarce resources is critical to entrepreneurial success (Liao, Welsh \& Moutray, 2008). These resources include human capital in the form of related experience and education, social capital in the form of useful social networks, and financial capital (Chandler \& Hanks, 1998). These resources are critical because they influence entrepreneurs' confidence and assurance in their ability to perform tasks and roles associated with entrepreneurship (Marshall et al., 2020). This study focuses on two types of resources; financial and capital resources. Financial capital obtained externally through investors or internally by business owners represents money available for running the operations of the business (Klyver \& Schenkel, 2013). Meanwhile, social capital relates to the relationship among members in the teams and external stakeholders such as investors, suppliers, and customers (Adler \& Kwon, 2002). Social capital includes information, social support, financing from these relational networks and supports the growth and performance of the business (Hitt et al., 2002).

The greater the access of the microentrepreneurs to financial and social capital may enhance the microenterprise capability and performance. Thus, during pandemic and MCO, the government provides financial capital to the affected microenterprises and the government agencies responsible to ensure the access of microenterprises to the social capital in the form of online training and network. In Malaysia, micro-business development and social media provide an effective medium to enhance the social capital and networking of microentrepreneurs (Harun et al., 2021).

\section{Covid-19 and Stimulus Package}

The global COVID-19 pandemic des not only affect global health condition but also impending the structure of global economic order. The MCO, lockdown, and social distancing are amongst the government effort to control the spread of the COVID-19 virus. The closure of economic sectors has a great impact on Malaysia's economy especially the MSMEs. The government has prepared several stimulus packages to assist businesses in the country. On 27 March 2020, the Prime Minister announced the Economic Stimulus Package Prihatin 
Rakyat (PRIHATIN) worth RM250 billion. A special PRIHATIN Grant amounting to RM2.1 billion is established for eligible microenterprises. Each eligible company will receive a grant of RM3,000 (Ayman, 2020). In early January 2021, Malaysia announced the Malaysian Economic and Rakyat's Protection Assistance Package (PERMAI) to support businesses. As to assist the micro-enterprises, the implementation of micro-credit schemes under PRIHATIN and PENJANA valued at RM1 billion is also expedited.

The government has also allocated RM300 million for providing training on digitalization for micro-entrepreneurs to switch to the e-commerce platform. For further enhancement of micro-credit for microenterprise, Bank Simpanan Nasional (BSN), the Small and Medium Enterprises Corporation, Government agencies MARA, National Entrepreneur Group Economic Fund (TEKUN) have allocated a further RM1.5 billion at 3\% interest (Ayman, 2021). Pakej Perlindungan Rakyat dan Pemulihan Ekonomi (PEMULIH) is announced by the Prime Minister on 28 June 2021 as a respond for the extension of the MCO 3.0. Among the incentives announced is the continuation of a wage subsidy program, special grant for MSMEs, additional payment for Prihatin Special Grant receivers, government guarantee scheme, enhancement of micro-loans, loan moratorium for MSMEs, electricity discounts, and small entrepreneur digitalization empowerment program (Ayman, 2021b).

\section{Methodology}

This study used a qualitative approach using semi-structured interviews via telephone. This method was selected to gain insights from the microentrepreneurs on the challenges they faced and their business strategy to survive during the crisis of COVID-19. Lo lacono, Symonds \& Brown (2016) proposed the use of internet based-method of communication using voice and video across the internet via a real-time connection. The phone interview is selected for this study since some of the micro-entrepreneurs prefer to have a phone interview and it is a suitable method during the pandemic. Although it cannot completely replace face-to-face interaction, it works well as an alternative collection tool for qualitative study (Lo lacono et al., 2016).

Five micro-entrepreneurs were selected with the following criteria:

(i) registered their businesses with City Council A (urban area) and District Council B (semi-urban area) in Perak,

(ii) has been running the business for more than four years; and

(iii) annual sales less than RM300,000 with fewer than five employees.

The sample was selected through the non-probability sampling technique (purposive sampling) as the criteria of the respondents are already set. The interviews were conducted in the third and fourth week of June 2021 and recorded with the respondents' permission. The interview recordings were transcribed and analyzed using the thematic analysis approach. Using NVIVO-12 software, the data were coded and analyzed to search for patterns and emerging themes. Table 2 lists the business and background information of the respondents. 
Table 2: Respondents' background and business information

\begin{tabular}{|c|c|c|c|c|c|c|}
\hline Respondent & Gender & $\begin{array}{l}\text { Types of } \\
\text { business }\end{array}$ & Category & Location & $\begin{array}{l}\text { Business } \\
\text { experience }\end{array}$ & $\begin{array}{l}\text { No of } \\
\text { staffs }\end{array}$ \\
\hline Resp 1 & Male & Grocery & Essential & $\begin{array}{l}\text { Semi- } \\
\text { urban }\end{array}$ & 10 years & 3 \\
\hline Resp 2 & Female & Saloon & $\begin{array}{l}\text { Non- } \\
\text { essential }\end{array}$ & Urban & 8 years & 2 \\
\hline Resp 3 & Female & Dobby & $\begin{array}{l}\text { Non- } \\
\text { essential }\end{array}$ & $\begin{array}{l}\text { Semi- } \\
\text { urban }\end{array}$ & 7 years & 1 \\
\hline Resp 4 & Male & Food & Essential & $\begin{array}{l}\text { Semi- } \\
\text { urban }\end{array}$ & 11 years & 2 \\
\hline Resp 5 & Female & $\begin{array}{l}\text { Traditional } \\
\text { food }\end{array}$ & Essential & Urban & 12 years & 1 \\
\hline
\end{tabular}

\section{Results and Discussion}

Findings from the data highlighted two sets of themes according to the two research objectives. The themes that emerged for challenges faced by microentrepreneurs are (i) lack of financial resources and (ii) supply chain issues. For business strategy used to survive during the pandemic and MCO, the major themes are related to (i) access to financial capital and (ii) access to social capital and networking.

\section{Lack of Financial Resources}

The implementation of MCO 3.0 has further caused financial implications to microentrepreneurs especially those under non-essentials business. Respondent 2 who is the owner of the hair saloon stated her business was impacted due to the closure of the business operation. She still needs to pay for the rental of the premises and wages for her staff. Similar to respondent 3 , the owner of the dobby shop, expressed her worry because of her sudden decline in her business income. She needs to borrow from her mother as her saving is already used to sustain during MCO 1.0. However, those selling essential items do not facing bad financial problems since they still can continue operations during MCO. For respondent 4 , his business capital is still sufficient to run the business. But he needs to spend more to buy a larger quantity of stocks because of supplier did not travel frequently from Ipoh.

\section{Supply Chain Issues}

Furthermore, the major challenge faced by microentrepreneurs is on the supply chain issues. For respondent 1 who is selling local products in the markets such as ikan kering, kerisik and coconut milk revealed even though there are demands of the products, it is difficult to ensure the stocks are sufficient because the suppliers take a longer time to deliver stocks due to restriction of cross-district travel. For respondent 5 who is selling traditional kuih, instead of selling six types of kuih daily, now she is only able to make four types of kuih because of a shortage of materials like grated coconut. She also mentioned that her customers are normally working people but due to $\mathrm{MCO}$, there is a reduction in the number of customers daily. However, she is still grateful because there are still customers coming to her stall although the number of customers is slightly decrease compared to before MCO. 


\section{Access to Financial Capital}

Meanwhile, the respondents have mixed opinions on the financial aids provided by the government. Other than the stimulus package by Federal Government, the Perak State government also provides financial support for these microentrepreneurs affected under Perak Stimulus Package 2021 announced on $2^{\text {nd }}$ June 2021. For respondents 4 and 5 , the oneoff RM300 financial assistance for registered micro-businesses and one-month stall rental exemption for micro-businesses registered with the local authority of Perak are really helpful to sustain their businesses. However, they admitted that the one-off payment is insufficient to cover the impact if MCO is prolonged. For respondent 2, she still needs to pay for fixed overheads such as rental and staff salaries during the closure of her business. Although she applied for the six months loan moratorium, she is still worried because her business currently has no income. She is intent to apply for the newly announced government incentive since she never applies for any government incentive package during MCO 1.0. She is also considering applying for an additional loan if the future conditions do not permit her business to sustain although she tries to avoid adding any liabilities to the business.

\section{Access to Social Capital and Networking}

Respondent 3 informed that government agency such as Sekretariat Usahawan Negeri Perak (STEP) assists her because only by using Facebook, she able to get access to free online courses, especially on digitalized marketing. Currently, she ventured into selling online baby clothes which can support the impact of the closure of her dobby shop. Similar to respondent 2, upon suggestion from her friend in Kelab Usahanita Perak, she is now selling cosmetic products through dropship while waiting for her saloon to operate. For respondent 1, with the help of her daughter, he now ventured into selling his products online using Facebook. There are also customers ordered through phone and upon request, he provides delivery for nearby customers. On the other hand, respondent 5 views that as long as she has sufficient cash to run the business, she does not need to venture into online marketing. She hopes her business will be back to normal after MCO.

\section{Conclusion}

This study provides evidence on the challenges faced by the microentrepreneurs and how the financial and social capital influence their strategy to sustain during MCO 3.0. The findings revealed two main obstacles for microentrepreneurs in Perak; lack of financial resources and supply chain issues. These findings are consistent with the previous studies of Tajudin et al (2021); Hamdan et al (2021); Fabeil et al (2020) which found microenterprises severely impacted because of a lack of financial resources. For non-essential microenterprises, they require financial assistance because of lost business income due to business closure as compared to essential microenterprises. As for micro-enterprises selling essential items, generally, they can survive and still have sufficient capital to run the business. Besides, it is interesting to find that younger microentrepreneurs are easily adapted to the new norm and adjustable to new ways of conducting business as compared to older microentrepreneurs. The younger microentrepreneurs have greater exposure to social media thus, improving their social connection and information accessibility in finding new ways of business operations.

Interestingly, this study found that microentrepreneurs rely on online marketing and skills development training provided by government agencies to plan their business survival strategies during the pandemic. From the geographical context, microentrepreneurs in the 
semi-urban areas also participate in programs similar to microentrepreneurs in the urban areas since they are already exposed to the use of social media. Thus, government agencies involved play a crucial role in helping microentrepreneurs to survive especially during the crisis. This study proposed the government agencies focus on their specialized knowledge program such as online marketing, product development, pricing strategies, handling customer databases, and supply chain management as part of microentrepreneurs business strategy planning.

Moreover, these microentrepreneurs took certain strategies to ensure the survival and sustainability of their businesses. Access to financial capital such as financial aids through stimulus package and social capital like networks and social media are important for microentrepreneurs to decide on business strategy. The economic stimulus package provided by the governments is among contributing elements that help this small business operate during and after MCO (Hamdan et al., 2021). The financial and social capital could enhance microentrepreneurs' confidence and persistence in planning their strategies, particularly during this challenging period due to COVID-19 pandemics. This finding provides insights on the importance of microentrepreneurs' access to these resources since it would develop the self-efficacy of microentrepreneurs and the self-efficacy would lead to greater microentrepreneurs' well-being (Marshall et al., 2020).

Consistent with the previous literature, the findings of this study revealed financial aids provided by the federal government and state government bring hope to the microentrepreneurs in facing challenges during MCO. In terms of support provided by government agencies, entrepreneurial government agencies play a significant role because other than financing aids, they provide an online platform and network for microentrepreneurs to enhance their skills and knowledge to venture into new business opportunities. Social support from family members is also crucial for microentrepreneurs' self-belief, thus decreasing the possibility of future business failure. Finally, it is suggested future studies should examine the variables that influence self-efficacy and entrepreneurial persistence among microentrepreneurs as these factors are important for the sustainability strategy of the business. Furthermore, the effectiveness of microenterprises development programs should be evaluated on their outcomes and impact on the survival of the microenterprises business.

\section{References}

Adler, P. S., \& Kwon, S. W. (2002). Social capital: Prospects for a new concept. Academy of management review, 27(1), 17-40.

Ayman, F. M. (2020). Malaysia's PENJANA Stimulus Package: Key Features. ASEAN Briefing. https://www.aseanbriefing.com/news/malaysias-penjana-stimulus-package-keyfeatures/

Ayman, F. M. (2021). Malaysia Introduces Pemerkasa Plus Economic Stimulus Package. ASEAN Briefing. https://www.aseanbriefing.com/news/malaysia-introduces-pemerkasa-pluseconomic-stimulus-package/

Ayman, F. M. (2021b). Malaysia's Pemulih Stimulus Package: Supporting Businesses and Individuals. ASEAN Briefing. https://www.aseanbriefing.com/news/malaysias-pemulihstimulus-package-supporting-businesses-and-individuals/ 
Barney, J. (1991). Firm resources and sustained competitive advantage. Journal of Management, 17(1), 99-120.

Chandler, G. N., \& Hanks, S. H. (1998). An examination of the substitutability of founders human and financial capital in emerging business ventures. Journal of business venturing, 13(5), 353-369.

Baluku, M. M., Kikooma, J. F., Bantu, E., \& Otto, K. (2018). Psychological capital and entrepreneurial outcomes: the moderating role of social competencies of owners of micro-enterprises in East Africa.

Bose, B. (2013). Financing of Micro, medium, and small scale enterprises in India Key Challenges. IOSR Journal of Economics and Finance, 1 (1 (May. - Jun. 2013)), 1-4.

Chandler, G. N., \& Hanks, S. H. (1998). An examination of the substitutability of founders human and financial capital in emerging business ventures. Journal of business

Che Omar, A. R., Ishak, S., \& Jusoh, M. A. (2020). The impact of Covid-19 Movement Control Order on SMEs' businesses and survival strategies. Malaysian Journal of Society and Space, 16(2), 139-150. https://doi.org/10.17576/geo-2020-1602-11

Fabeil, N. F., Pazim, K. H., \& Langgat, J. (2020). The Impact of Covid-19 Pandemic Crisis on Micro-Enterprises: Entrepreneurs' Perspective on Business Continuity and Recovery Strategy. Journal of Economics and Business, 3(2). https://doi.org/10.31014/aior.1992.03.02.241

Hamdan, N. H. B., Kassim, S. B. H., \& Lai, P. C. (2021). the Covid-19 Pandemic Crisis on MicroEntrepreneurs in Malaysia: Impact and Mitigation Approaches. Journal of Global Business and Social Entrepreneurship (GBSE), 7(20), 52-64. Retrieved from www.gbse.com.my

Harun, R., Sabri, M. S., \& Ahmad, S. (2021). The Influence Of Social Media On Social Capital : Development Of The Influence Of Social Media On Social Capital : Development Of Small Business Growth. Proceeding of 2nd International Conference on Multi-Disciplinary Research, (January), 185-196.

Hitt, M. A., Ireland, R. D., Camp, S. M., \& Sexton, D. L. (2002). Strategic entrepreneurship: Integrating entrepreneurial and strategic management perspectives. Strategic entrepreneurship: Creating a new mindset, 1, 16.

Khaw, N. (2019) The Edge Malaysia Weekly, September 2, 2019 - September 08, 2019.

Klyver, K., \& Schenkel, M. T. (2013). From resource access to use: Exploring the impact of resource combinations on nascent entrepreneurship. Journal of Small Business Management, 51(4), 539-556.

Lacina, L., \& Vavřina, J. (2013). The Impact Of Financial And Economic Crisis On SME's in Greece And Ireland. Acta Universitatis Agriculturae Et Silviculturae Mendelianae Brunensis, 61(4), 1005-1016. https://doi.org/10.11118/actaun201361041005

Larson, D. W., \& Shaw, T. K. (2001). Issues of microenterprise and agricultural growth: do opportunities exist through forward and backward linkages?. Journal of Developmental Entrepreneurship, 6(3), 203-220.

Liao, J. J., Welsch, H., \& Moutray, C. (2008). Start-up resources and entrepreneurial discontinuance: The case of nascent entrepreneurs. Journal of Small Business Strategy, 19(2), 1-16.

Lo lacono, V., Symonds, P., \& Brown, D. H. (2016). Skype as a tool for qualitative research interviews. Sociological research online, 21(2), 103-117.

Marshall, D. R., Meek, W. R., Swab, R. G., \& Markin, E. (2020). Access to resources and entrepreneurial well-being: A self-efficacy approach. Journal of Business Research, 
120(August), 203-212. https://doi.org/10.1016/j.jbusres.2020.08.015

Mittal, V., \& Raman, T. V. (2021). Examining the determinants and consequences of financial constraints faced by Micro, Small, and Medium Enterprises' owners. (2006). https://doi.org/10.1108/WJEMSD-07-2020-0089

Radzi, M. N. A., Lee, K. E., Hashim, H., Ali, M. A. F., Saidi, N. A., \& Hasbollah, H. R. (2020). Charity Sees The Need, Not The Cause : The Strategic Csr During The Pandemic Outbreak. Palarch's Journal of Archaeology of Egypt/Egyptology, 17(4), 485-498.

Mustapa, A. N., \& Mohamad, A. (2021). Malaysian Government Business Support and Assistance for Small and Medium Enterprises: A Case of COVID-19 Pandemic Crisis. In Modeling Economic Growth in Contemporary Malaysia. Emerald Publishing Limited.

Sabli, H. M., Latiff, H. A., \& Wahi, M. F. B. (2018). Review On Factors Affecting Micro Entrepreneur Performance In Malaysia: A Conceptual Model. International Journal of Academic Research in Progressive Education \& Development, 7(3).

Singh, P., \& Kaur, C. (2019). Factors determining financial constraint of SMEs : a study of unorganized manufacturing enterprises in India Factors determining financial constraint of SMEs : a study of unorganized manufacturing enterprises in India. Journal of Small Business \& Entrepreneurship, $0(0), 1-19$. https://doi.org/10.1080/08276331.2019.1641662

Tajudin, P. N. M., Rahim, N. A. A., Idris, K., \& Arshad, M. M. (2021). Weathering the economic impact of COVID-19: Challenges faced by microentrepreneurs and their coping strategies during movement control order (MCO) in Malaysia. Pertanika Journal of Social Sciences and Humanities, 29, 271-290. https://doi.org/10.47836/pjssh.29.s1.15

Mustapa, W. N., Al Mamun, A., \& Ibrahim, M. D. (2018). Development Initiatives, MicroEnterprise Performance, and Sustainability. International Journal of Financial Studies, 6(74), 1-15. https://doi.org/10.3390/ijfs6030074 